\title{
ARBITRARINESS AND THE DEATH PENALTY IN AN INTERNATIONAL CONTEXT
}

\author{
MARY K. NEWCOMER
}

It is virtually self-evident to me now that no combination of procedural rules or substantive regulations ever can save the death penalty from its inherent constitutional deficiencies. The basic question-does the system accurately and consistently determine which defendants "deserve" to die?-cannot be answered in the affirmative. ... The problem is that the inevitability of factual, legal, and moral error gives us a system that we know must wrongly kill some defendants, a system that fails to deliver the fair, consistent, and rehable sentences of death required by the Constitution. ${ }^{1}$

\section{INTRODUCTION}

In 1994, Supreme Court Justice Harry Blackmun repudiated his past support for the death penalty ${ }^{2}$ and declared that he could "no longer... tinker with the machinery of death." Justice Blackmun stated that his experience with the administration of the death penalty im the United States finally had led him to realize that the Supreme Court's efforts to provide substantive and procedural safeguards to ensure "fairness, reasonable consistency, and absence of error" in the imposition of the death penalty are doomed to failure. Thus, the death penalty simply "cannot be administered im accord with our Constitution." Justice Blackmun argued that the Supreme Court's jurisprudence under the Eighth Amendment of the Constitution, which prohibits states from inflicting "cruel and imusual pumshment," established two indis-

1. Callins v. Collins, 114 S. Ct. 1127, 1130 (1994) (Blackmun, J., dissenting from denial of certiorari).

2. See id. at 1130 n.1.

3. Id. at 1130 .

4. Id. at 1129 .

5. Id. at 1137.

6. U.S. CONST. amend. VIII. 
pensable but inconsistent requirenents for the constitutional imposition of the death penalty. According to Furman v. Georgia ${ }^{7}$ and its progeny, ${ }^{8}$ the death penalty must be administered "consistently and rationally, [or] it may not be adininistered at all." On the other hand, under Woodson v. North Carolina ${ }^{10}$ and Lockett $v$. Ohio ${ }^{11}$ the death penalty also must be administered fairly, based on an individualized examination of the defendant and his crime. ${ }^{12}$ According to the Supreme Court, these requirements are balanced appropriately when the class of defendants eligible for the death penalty is narrowed according to "clear and objective standards that provide specific and detailed guidance,"13 and when the sentencer, as to the narrowed class of defendants, retains the discretion to consider any mitigating factor relevant to the defendant's character or crime. ${ }^{14}$ According to Justice Blackmun, however, "this approach ... simply reduces, rather then eliminates, the number of people subject to arbitrary sentencing."15 Ultimately, "the decision whether a human being should live or die is so inherently subjective-rife with all of life's understandings, experiences, prejudices, and passions-that it inevitably defies the rationality and consistency required by the Constitution."16

At the time that he reached this conclusion, however, Justice Blackmun was the only Supreme Court Justice willing to "adinit the futility" of the attempt to ensure the consistent and fair ad-

7. 408 U.S. 238 (1972).

8. See, e.g., Eddings v. Oklahoma, 455 U.S. 104 (1982); Gregg v. Georgia, 428 U.S. 153 (1976).

9. Callins, 114 S. Ct. at 1131 (citing Eddings, 455 U.S. at 112).

10. 428 U.S. 280 (1976).

11. 438 U.S. 586 (1978).

12. See id. at 604 (plurality opinion) (holding that "the Eighth and Fourteenth Amendments require that the sentencer ... not be precluded from considering, as a mitigating factor, any aspect of a defendant's character or record and any of the circumstances of the offense that the defendant proffers as a basis for a sentence less than death") (emphasis omitted); Woodson, 428 U.S. at 303 (plurality opinion) (holding that North Carolina mandatory death penalty statute was unconstitutional because of its "failure to allow the particularized consideration of relevant aspects of the character and record of each convicted defendant before [sentencing him to death]").

13. Godfrey v. Georgia, 446 U.S. 420, 428 (1980) (plurality opinion) (quoting Gregg, 428 U.S. at 198).

14. Callins v. Collins, 114 S. Ct. 1127, 1134 (1994) (Blackmun, J., dissenting from denial of certiorari).

15. Id.

16. Id. at $1134-35$. 
ministration of the death penalty. ${ }^{17}$ Today, after Justice Blackmun's retirement, the full Court continues to presume that judges, juries, and prosecutors, provided with statutory sentencing guidelines for the imposition of the death penalty, make fair and reliable sentencing decisions based on relevant characteristics of defendants' characters and crimes. ${ }^{18}$ Yet statistical evidence ${ }^{19}$ and luman intuition, ${ }^{20}$ both of which strongly suggest that death penalty decisions in fact are influenced by numerous extralegal factors, undermine the presumption that the death penalty can be administered fairly and in accordance with the Constitution. Nonetheless, such evidence has convinced neither the Supreme Court nor federal and state legislatures to abandon the use of a punishment that is demonstrably inconsistent with the command of the Constitution. ${ }^{21}$

17. Id. at 1137 .

18. See, e.g., Clemons v. Mississippi, 494 U.S. 738, 749 (1990) ("[S]tate appellate courts can and do give each defendant an individualized and reliable sentencing determination based on the defendant's circumstances, his background, and the crime."); McCleskey v. Kemp, 481 U.S. 279, 297 (1987) ("Because discretion is essential to the criminal justice process, we would demand exceptionally clear proof before we would infer that the discretion has been abused.").

19. See, e.g., McCleskey, 481 U.S. at 286-87 (summarizing a sophisticated and comprehensive statistical study of Georgia death penalty decisions demonstrating a significant disparity in the imposition of the death penalty based on the race of the victim and, to a lesser extent, the race of the defendant); William J. Bowers, The Pervasiveness of Arbitrariness and Discrimination Under Post-Furman Capital Statutes, 74 J. CRIM. L. \& CRIMINOLOGY 1067 (1983) (presenting extensive evidence of extralegal influences on death penalty decisions and demonstrating inherent arbitrariness in adininistration of death penalty).

20. See supra text accompanying note 16.

21. One commentator concluded, after surveying the use by Supreme Court Justices of empirical social science evidence regarding the practical application of the death penalty, that

[r] esearch studies almost invariably have produced evidence that is inconsistent with the premises that the death penalty is administered evenhandedly and that capital punishment is effective or necessary to serve deterrence and incapacitation objectives. Justices writing lead opinions frequently have professed imcertainty and indifference about empirical evidence concerning the practical operation of death penalty systens, have adopted principles of adjudication that make social fact propositions subsidiary or irrelevant to governing decisional premises, and have proclaimed incompetence to scrutmize basic facts about capital punishment administration.

James R. Acker, A Different Agenda: The Supreme Court, Empirical Research Evidence, and Capital Punishment Decisions, 1986-1989, 27 LAW \& SoC'Y REV. 65, 81 (1993) (citations omitted). For examples of increasing legislative support for the death penalty, see Violent Crime Control and Law Enforcement Act of 1994, Pub. L. No. 103-322, §§ 60003-60024, 108 Stat. 1796, 1968-82 (1994) (to be codified in scattered sections of 18 U.S.C.) (increasing the number of federal crimes for which the death penalty may be imposed); Death Penalty, 1995 N.Y. Laws ch. 1 (McKinney) (reinstating death penalty in 
This Note demonstrates the inevitable arbitrariness of the administration of the death penalty, and thus its inconsistency with the Constitution's prohibition against cruel and unusual punishment, in a new context. It does not, as have many prior arguments against the death penalty, ${ }^{22}$ rely on empirical evidence of discrepancies in capital sentencing decisions. Instead, it provides a concrete example of how extrinsic forces-in this case, the international human rights obligations of States ${ }^{23}$ with which the United States has extradition agreements-bear on death penalty decisions in the United States. The Note asserts that the influence of these extrinsic factors makes the death penalty arbitrary because the penalty is imposed in an international context in which circumstances unrelated to a defendant's character or crime can affect the outcome of death penalty decisions. In fact, the Note argues that both components of the procedural requirenients for the constitutional imposition of the death penalty are violated. Finally, the Note concludes that the death penalty is not only arbitrary as administered within the existing international context, but within other contexts as well. Death penalty sentencing schemes operate within many environments-social, political, and economic-in addition to the international political system described herein. Although the influence on death penalty decisions of extrinsic factors in those additional contexts is less amenable to concrete demonstration than the mfluence exerted in the international context, this Note asserts that the influence of extrinsic factors is, nonetheless, equally unavoidable.

Part I summarizes the Supreme Court's death penalty jurisprudence under the Eighth Amendment to the Constitution, focusing particularly on the procedural requirements the Court has established in an effort to prevent the arbitrary and capricious administration of the death penalty. Part II then describes four international cases that provide a framework for analyzing States' international human rights obligations with respect to extradition to the

New York); John Sanko, Lawyers Back Air Tests, Toughen the Death Penalty, RockY MT. NEws, Jan. 29, 1995, at 38A (discussing Colorado law passed to strengthen the death penalty by giving sentencing authority to judges, and backed by some voters on the ground that it is "too easy" for defense attorneys to find one juror opposed to the death penalty).

22. See supra note 19.

23. Throughout this Note, "State" with a capital "S" will refer to a foreign nation, and "state" with a lower-case "s" will refer to a state within the United States. 
United States of individuals likely to face the death penalty. Part III proposes that the influence of those human rights obligations on the outcome of death penalty decisions in the United States renders the administration of the death penalty arbitrary and capricious. Finally, the Note concludes by analogizing the international extradition cases to other extrinsic environmental factors, thus providing a framework for understanding the inevitable and pervasive influence of extrinsic factors on all death penalty decisions.

\section{ARBITRariness AND the DeAth PENALTy IN THE UNITED STATES}

The Eighth Amendment to the Constitution provides that "cruel and unusual punishments [shall not be] inflicted."24 Although the Supreme Court has never held that punishment by death is per se "cruel and unusual punishment," nized that the death penalty is umique because of its severity and irrevocability. ${ }^{26}$ Given the severe nature of the penalty, the Court has required that extraordinary procedural safeguards accompany its administration, because such a severe penalty will be cruel and unusual if administered in an arbitrary and capricious mauner. ${ }^{27}$ The Court first announced the principle that the death penalty may be imposed only if it is administered fairly and nonarbitrarily in the case of Furman v. Georgia. The Court held ${ }^{28}$ that the

24. U.S. CONST. amend. VIII. Although the Supreme Court has never defined clearly what is meant by the phrase "cruel and unusual punishments," it has held that a punishment is "cruel and unusual" if it clearly is disproportionate to the offense for which it is imposed, see Robmson v. California, 370 U.S. 660, 667 (1962); Weems v. United States, 217 U.S. $349,366-67(1910)$, or if it is so inappropriate or physically or mentally painful that it violates the "dignity of man." See Trop v. Dulles, 356 U.S. 86, 100 (1958); Weems, 217 U.S. at 366.

25. See In re Kemmler, 136 U.S. 436,447 (1890) (holding that punishment by death is not cruel unless the method of execution is inhuman or barbarous).

26. Furman v. Georgia, 408 U.S. 238, 306 (1972) (Stewart, J., concurring).

27. Id. at $309-10$.

28. Five justices concurred with the judgment that the penalty as imposed was cruel and unusual. However, because the Justices differed in their reasons for supporting the judgment, only the opinions of Justices Stewart and White, who concurred on the most narrow grounds, represent the opinion of the Court. See Gregg v. Georgia, 428 U.S. 153, 169 n.15 (1976) ("[T]he holding of the Court [is] . . . that position taken by those Meinbers who concurred in the judgments on the narrowest grounds."); see also MARK Tushnet, THE DEATH PENALTY 48 (1994) (summarizing grounds on which the five Justices concurred). 
death penalty as administered in the United States at that time was cruel and unusual, and thus unconstitutional, because it was "wantonly and ... freakishly imposed" 29 upon "a capriciously selected random handful" of convicted criminals. ${ }^{30}$

Four years after Furman, the Supreme Court revisited the issue of arbitrariness and the death penalty in Gregg v. Georgia, and indicated that the inclusion of certain procedural safeguards in death penalty sentencing schemes could eliminate unconstitutional arbitrariness from the imposition of the penalty. ${ }^{31}$ In Gregg, the Court held that the Georgia death penalty statute, which was revised after Furman to imclude sentencing guidelines and judicial review provisions designed to prevent the arbitrary imposition of the death penalty, was constitutional. ${ }^{32}$ The revised statute ${ }^{33}$ provided that all capital trials must proceed in two stages. In the first stage, the jury determined the defendant's guilt or innocence. ${ }^{34}$ If the jury convicted the defendant, the trial proceeded to the penalty stage. During the penalty stage, the jury considered additional evidence of aggravating and mitigating circumstances, ${ }^{35}$ and based its sentencing decision on consideration of all the circumstances presented. The jury could not, however, sentence the defendant to death unless it affirmatively found, beyond a reasonable doubt, that at least one of ten aggravating circumstances enumerated in the statute was present. ${ }^{36}$ If the jury sentenced the defendant to

29. Furman, 408 U.S. at 310 (Stewart, J., concurring).

30. Id. at 309-310; see also id. at 311-12 (White, J., concurring) (finding the death penalty cruel and unusual because it was imposed too infrequently to serve any legitimate retributive or deterrent function in society); id. at 274 (Brennan, J., concurring) (arguing that "the State does not respect human dignity when, without reason, it inflicts upon some people a severe punishment that it does not inflict upon others"); id. at 364-65 (Marshall, J., concurring) (citing statistical evidence that the death penalty is disproportionately imposed on racial minorities, the poor, and the disadvantaged to support his argument that the death penalty is cruel and unusual).

31. 428 U.S. 153 (1976).

32. Id. at $206-07$.

33. See GA. CODE ANN. §§ 27-2534.1, -2537 (Harrison 1978). The current statute, which is substantially the same as that considered in Gregg, is codified at GA. CODE ANN. §§ 17-10-30 to $-31,-35$ (Michie 1990).

34. Gregg, 428 U.S. at 163.

35. Id. at 163-64. At the penalty stage, the strict evidentiary rules applicable to the guilt stage do not apply. Id. at 164 .

36. Id. at 164-65. The aggravating circumstances enunerated in the statute were:

(1) The offense of murder, rape, armed robbery, or kidnapping was committed by a person with a prior record of conviction for a capital felony[, or the offense of murder was committed by a person who has a substantial history of serious assaultive crimmal convictions]. 
death, the decision automatically was appealed to the state supreme court, which was required to review the decision to determine

(1) Whether the sentence of death was imposed under the influence of passion, prejudice, or any other arbitrary factor, and

(2) Whether ... the evidence supports the jury's or judge's finding of a statutory aggravating circumstance as enumerated ... and

(3) Whether the sentence of death is excessive or disproportionate to the penalty imposed in similar cases, considering both the crime and the defendant. ${ }^{37}$

After reiterating the principle that punishment by death is not unconstitutional per se, ${ }^{38}$ the Court considered the constitutionality of the death penalty as administered under the Georgia statute. The Court stated that Furman had established the principle that

(2) The offense of murder, rape, armed robbery, or kidnapping was committed while the offender was engaged in the commission of another capital felony, or aggravated battery, or the offense of murder was committed while the offender was engaged in the commission of burglary or arson in the first degree.

(3) The offender by his act of murder, armed robbery, or kidnapping knowingly created a great risk of death to more than one person in a public place by means of a weapon or device which would normally be hazardous to the lives of more than one person.

(4) The offender committed the offense of inurder for himself or another, for the purpose of receiving money or any other thing of monetary value.

(5) The murder of a judicial officer, former judicial officer, district attorney or solicitor or former district attorney or solicitor during or because of the exercise of his official duty.

(6) The offender caused or directed another to commit murder or committed inurder as an agent or employee of another person.

(7) The offense of murder, rape, armed robbery, or kidnapping was outrageously or wantonly vile, horrible or mhuman in that it involved torture, depravity of mind, or an aggravated battery to the victim.

(8) The offense of murder was committed against any peace officer, corrections employee or fireman while engaged in the performance of his official duties.

(9) The offeuse of murder was committed by a person in, or who has escaped from, the lawful custody of a peace officer or place of lawful confinement.

(10) The murder was committed for the purpose of avoiding, interfering with, or preventing a lawful arrest or custody $\mathrm{m}$ a place of lawful confinement, of himself or another.

GA. CODE ANN. $\S 27-2534.1$ (b) (Harrison Supp. 1975) (quoted in Gregg, 428 U.S. at 165 n.9). The current death penalty statute, codified at GA. CODE ANN. \$ 17-10-30(b) (Michie 1990), lists identical aggravating circumstances, except that the bracketed ([ ]) portion of (1) was deleted after it was found to be unconstitutionally vague. See Arnold v. State, 224 S.E.2d 386, 391-92 (Ga. 1976).

37. GA. CODE ANN. $\S 27-2537$ (Harrison Supp. 1975) (quoted in Gregg, 428 U.S. at 166-67); see also GA. CODE ANN. $\& 17-10-35$ (c) (Michie 1990) (using same language).

38. Gregg, 428 U.S. at 187. 
the death penalty "[can]not be imposed under sentencing procedures that create[] a substantial risk that it [will] be inflicted in an arbitrary and capricious manner." ${ }^{39}$ The Court then held that the Georgia statute did not create such a risk because it provided two mechanisms to ensure that the death penalty would not be administered arbitrarily. First, the statute narrowed the crimes for which the death penalty could be imposed and provided guidance to jurors in making the sentencing decision. ${ }^{40}$ The Court found that

[the statutory enumeration of aggravating circumstances and the requirement that the jury consider all appropriate aggravating and mitigating circumstances] require the jury to consider the circumstances of the crime and the criminal before it recommends sentence. ... [T] [Te jury's attention is directed to the specific circumstances of the crime ... [and] is focused on the characteristics of the person who committed the crime .... As a result, while some jury discretion still exists, "the discretion to be exercised is controlled by clear and objective standards so as to produce non-discriminatory application. ${ }^{.41}$

Second, the statute provided for state supreme court review of all death sentences to ensure that none had been imposed arbitrarily or was disproportionate to the penalty imposed in similar cases. ${ }^{42}$ The Court also held that the discretion exercised by the prosecutor in deciding whether or not to bring a capital charge, and by the state governor or Board of Pardons and Paroles in deciding whether or not to pardon a defendant, did not create a "substantial risk" of arbitrary or capricious decisionmaking. The Court assumed that such actors in the criminal justice system would apply essentially the same standards as those enumerated for the jury, and the exercise of discretion thus would not be arbitrary. ${ }^{43}$

In Gregg v. Georgia, the Supreme Court accepted the principle that a system of procedural safeguards could serve as an effective inechanisin to eradicate arbitrariness from the administration of the death penalty. Subsequent cases clarified the specific procedural safeguards necessary to effectuate that eradication. As Justice Blackmun noted in Callins $v$. Collins, these procedural re-

39. Id. at 188.

40. Id. at $196-98$.

41. Id. at 197-98 (quoting Coley v. State, 204 S.E.2d 612, 615 (Ga. 1974)).

42. Id. at 198.

43. See id. at 199; see also id. at 225 (White, J., concurring). 
quirements generally have proceeded along two lines. ${ }^{44}$ First, procedures must be provided to ensure that the death penalty is administered in an "evenhanded, rational, and consistent" nianner. ${ }^{45}$ To satisfy this requirement, death penalty statutes must provide clear and objective standards that narrow the class of defendants upon whom the sentencing authority may impose the death penalty. ${ }^{46}$ Death penalty sentencing procedures also must provide for statewide judicial review of death sentences to ensure fairness and consistency in the administration of the penalty. ${ }^{47}$ State courts do not need to satisfy themselves that each death sentence is directly proportionate to punishments received by similar defendants for similar crimes. ${ }^{48}$ However, the Court has suggested that some automatic appeal to a court with statewide jurisdiction must be provided to ensure that all sentences are reviewed for general consistency with state sentencing patterns. ${ }^{49}$

44. See Callins v. Collins, 114 S. Ct. 1127, 1136-37 (1994) (Blackmun, J., dissenting from denial of certiorari) (summarizing procedural requirements and arguing that because the two requirements cannot simultaneously be guaranteed, the death penalty can never be administered in accord with the Constitution).

45. See Jurek v. Texas, 428 U.S. 262, 276 (1976) ("By providing prompt judicial review of the jury's decision in a court with statewide jurisdiction, Texas has provided a means to promote the evenhanded, rational, and consistent imposition of death sentences under law.") (quoted in Pulley v. Harris, 465 U.S. 37, 48-49 (1984), which held that direct proportionality review is not required by the Constitution, but implied that soine automatic appeal is necessary to ensure that death penalty sentences are reviewed for fairness and consistency).

46. See, e.g., Lewis v. Jeffers, 497 U.S. 764, 774 (1990) (reaffirming principle that death penalty sentencing scheme must direct and limit sentencer's discretion); Zant $v$. Stephens, 462 U.S. 862, 878 (1983) (holding that statutory aggravating circumstances perform "constitutionally necessary function" of narrowing class of death-eligible defendants); Godfrey v. Georgia, 446 U.S. 420, 428 (1980) (plurality opinion) (holding that death penalty scheme must "channel the sentencer's discretion by clear and objective standards that provide specific and detailed guidance") (quoted in Arave v. Creech, 113 S. Ct. 1534, 1540 (1993)). But see Arave, 113 S. Ct. at 1550 (Blackmun, J., dissenting) (arguing that majority provided its own meaning to unconstitutionally vague aggravating factor in Idaho's death penalty statute in order to avoid a fmding of unconstitutionality).

47. See Pulley v. Harris, 465 U.S. 37, 48-49 (1984) (citing Jurek v. Texas, 428 U.S. 262, 276 (1976)).

48. Pulley, 465 U.S. at 48.

49. Id. at 44 ("All of the new statutes [upheld in the post-Furman cases of Gregg v. Georgia, 428 U.S. 153 (1976), Proffitt v. Florida, 428 U.S. 242 (1976), and Jurek v. Texas, 428 U.S. 262 (1976)] provide for automatic appeal of death sentences."); id. at 49 ("[R]eferences to appellate review ... were focused not on proportionality review as such, but only on the provision of soine sort of prompt and automatic appellate review."). 
Second, the Court has held that procedural safeguards must ensure that the death penalty is administered fairly and based on "consideration of the character and record of the individual offender and the circumstances of the particular offense." cordance with the requirement, sentencing authorities must be permitted to consider "any aspect of the defendant's character or record and any of the circumstances of the offense that the defendant proffers" in mitigation. ${ }^{51}$ Furthermore, not only must sentencers be allowed to consider any aspect of the defendant's character and the circumstances of the crime, but they may only consider aspects of the defendant's character and crime in deciding whether or not to impose the death penalty. ${ }^{52}$

In sum, the Supreme Court's Eighth Amendment jurisprudence holds that the death penalty is unconstitutional if administered in an arbitrary and capricious manner. However, if procedural safeguards are provided to ensure the evenhanded and rational imposition of the death penalty upon consideration of all-and only-the circumstances of the defendant's character and crime, the Court will hold the death penalty scheme constitutional. Conversely, a death penalty scheme will be unconstitutional if it does not provide for the evenhanded and consistent imposition of the death penalty, or if it permits death penalty decisions to be made on the basis of factors other than the character of the defendant or the characteristics of the crime.

\section{INTERNATIONAL HUMAN RIGHTS OBLIGATIONS AND EXTRAdition to Face the DEATH PENALTy}

The continued imposition of the death penalty in the United States distinguishes this country from much of the international community. In recent years, international condemnation of the

50. Eddings v. Oklahoma, 455 U.S. 104, 112 (1982) (quoting Woodson v. North Carolina, 428 U.S. 280,304 (1976)).

51. Lockett v. Ohio, 438 U.S. 586, 604-05 (1978).

52. See Booth v. Maryland, 482 U.S. 496, 502 (1987) (holding that victim impact evidence is per se inadmissible in a capital sentencing proceeding because it is not related to the defendant's character or crime). Althougl the Supreme Court explicitly overruled Booth with regard to the admissibility of victim impact evidence in Payne v. Tennessee, 501 U.S. 808, 828-30 (1991), it did so on the ground that victin impact evidence may provide relevant information regarding a defendant's crime by clarifying the degree of liarm caused by the crime. Payne, 501 U.S. at 819. Thus, Payne did not alter the principle that only evidence relating to a defendant's character or crime is relevant to the decision regarding the imposition of the death penalty. 
death penalty as a form of punishment has been reflected in the decisions of a number of multimational human rights organizations. Before discussing the specific decisions, a brief description of the multmational human rights mstitutions that produced them may be helpful.

During the years after World War II, a strong international novement emerged, arguing for increased accountability for governments that violate the human rights of their citizens. ${ }^{53}$ This movement ultimately led to the formation of several international and regional treaties that obligated ratifying States, sometimes called "Contracting Parties," to respect certain basic rights of their citizens. Among these new treaties were the International Covenant for Civil and Political Rights (ICCPR), which was drafted and passed by the General Assembly of the Umited Nations and is open for ratification or accession ${ }^{54}$ to all members of the United Nations, ${ }^{55}$ and the European Convention for the Protection of Human Rights and Fundamental Freedoms (European Convention) ${ }^{56}$ which was drafted by the Council of Europe, an organization of thirty-eight European States.

To ensure the accountability of States that are party to international human rights treaties, most treaties provide for an enforcement body with the authority to review States' comphiance

53. John P. Humphrey, The International Law of Human Rights in the Middle Twentieth Century, in THE PRESENT STATE OF INTERnATIONAL LAW 75, 82-83 (Maarten Bos, ed. 1973). Historically, although treaties and custom required States to respect certain rights of aliens within their territories and allowed the State of which the alien was a national to seek compensation for violations of those rights, States had no international obligatious with respect to the treatment of their own citizens. Id. at 75-76.

54. An original signing party ratifies a treaty; later parties that did not sign the treaty may become obligated to its terms by accession. I OPPENHEIM'S INTERNATIONAL LAW $\S 602$, at $1226-27, \S 611$, at 1236-37 (Robert Jennings \& Arthur Watts eds., 9th ed. 1992). The practical significance, namely that the treaty provisions becoine binding on the ratifying or acceding party, is the same. Id.; see also Vienna Convention on the Law of Treaties, May 23, 1969, art. 11, 1155 U.N.T.S. 331, 335-36 (entered into force Jan. 27, 1980), reprinted in 8 I.L.M. 679, 685 (1969).

55. Intermational Covenant on Civil and Political Rights, U.N. GAOR 3d Comm., 21st Sess., Supp. No. 16, at 52, U.N. Doc. A/6316 (1966) (entered into force Mar. 23, 1976) [hereinafter ICCPR].

56. Convention for the Protection of Human Rights and Fundamental Freedoms, Nov. 4, 1950, 213 U.N.T.S. 221 (entered into force Sept. 3, 1953) [hereinafter European Convention]. Other regional agreements include the American Convention on Human Rights, Nov. 22, 1969, O.A.S. T.S. No. 36 (entered into force July 18, 1978), and The African Charter on Human and Peoples' Rights, June 27, 1981, O.A.U. Doc. CAB/LEG/67/3 Rev. 5 (1981) (entered into force Oct. 21, 1986). 
with their obligations. The enforcement body for the ICCPR is the United Nations Human Rights Committee (UNHRC), which has the authority to request and review reports on participating States' compliance with the Covenant's provisions. ${ }^{57}$ The UNHRC also has the authority, when the State has accepted UNHRC jurisdiction through accession to the Optional Protocol, to review complaints brouglit by individuals alleging State violations of rights guaranteed under the Covenant. ${ }^{58}$ After the UNHRC reviews an individual complaint and any response by the State, it issues its "views" regarding whether the State has violated the rights of the complamant. 59 The "views" of the UNHRC are not binding on the States party to the ICCPR and Optional Protocol, but they generally are considered to be authoritative interpretations of the Covenant, and may provide political ammunition for domestic and international opposition to States' human rights violations. ${ }^{60}$ In addition, the Committee recently has adopted new measures, including the appointment of a "Special Rapporteur for the FollowUp of Views," to monitor compliance with its "views."

The enforcement meclianisin of the European Convention is both more complex and nore effective than that of the ICCPR. The European Convention establisled both a European Conımission of Human Rights and a European Court of Human Rights to enforce the provisions of the Convention. ${ }^{62}$ Allegations that a Contracting Party has violated its obligations under the Convention nay be submitted to the Commission by any other Contracting Party, ${ }^{63}$ or, if the Contracting Party has made a declaration recognizing the Commission's jurisdiction, by an individual, group of individuals, or nongovernmental organization. ${ }^{64}$ The Comnission

57. ICCPR, supra note 55 , arts. $28,40-42$.

58. Optional Protocol to the International Covenant on Civil and Political Rights, U.N. GAOR 3d Comm., 21st Sess. Supp., No. 16, at 59, U.N. Doc. A/6316 (1966) (entered into force Mar. 23, 1976) [hereinafter Optional Protocol].

59. Id. art. 5(4).

60. See JACK DONNELly, InTERNational Human Rights 59 (1993) ("[United Nations] findings ... have a certain authority, even though they are not legally binding. Doinestic human rights NGOs [non-governmental organizations] and other opposition groups may be able to draw support froin UN reports and resolutions. International NGOs and foreign governments may also use the findings.").

61. Siân Lewis-Anthony, Treaty-Based Procedures for Making Human Rights Complaints Within the UN System, in GUIDE TO INTERNATIONAL HUMAN RIGHTS PRACTICE 41, $48-49$ (Hurst Hannum ed., 2d ed. 1992).

62. European Convention, supra note 56, art. 19.

63. Id. art. 24.

64. Id. art. 25. At present, all Contracting Parties have accepted the right of individ- 
first attempts to secure a friendly settlement of matters referred to it. If it is unsuccessful, it may refer a report on the matter to the Committee of Ministers, which is composed of the Foreign Ministers of all member States of the Council of Europe. ${ }^{65}$ Alternatively, the Commission or Contracting Party involved may refer the matter to the European Court, as long as the Contracting Party has declared its acceptance of the European Court's jurisdiction. ${ }^{66}$ The decisions of the European Court are bimding on the Contracting Parties, ${ }^{67}$ and the European Court has the authority to "afford just satisfaction to the injured party."

In addition to increasing the accountability of States party to international human rights treaties, treaty enforcement bodies play an important role in interpreting and clarifying the meaning of the often vague provisions of international human rights agreenents. The decisional law of the enforcement bodies, particularly the European Court, provides States and individuals with clear notice of the States' international human rights obligations. One area in which this decisional law has played a significant role in clarifying and expanding States' obligations is the field of international extradition. ${ }^{69}$ Recent decisions of the European Court and UNHRC

ual petition; in fact, such acceptance has become a de facto condition for admission to the Council of Europe. Council of Europe, Explanatory Report to Protocol No. 11 to the European Convention on Human Rights, available in 15 HUM. RTS. L.J. 91, 98 (1994).

65. European Convention, supra note 56, arts. 28, 31.

66. Id. arts. 44, 46-47. Protocol No. 9 to the Convention granted a complaining party the right to refer its case to the European Court. Protocol No. 9 to the Convention For the Protection of Human Rights and Fundamental Freedoms, Nov. 6, 1990, arts. 3, 5, available in 30 I.L.M. 693, 694 (1991). In addition, a new protocol designed to "restructur[e] the control machinery" of the European Convention would, inter alia, make acceptance of the right of individual petition mandatory and allow an individual petitioner to refer a case to the European Court. Protocol No. 11 to the Convention for the Protection of Human Rights and Fundamental Freedoms, May 11, 1994, art. 34, available in 15 HUM. RTS. L.J. 86, 88 (1994). For a discussion of the significant structural changes proposed by Protocol No. 11, see Andrew Drzemczewski \& Jens Meyer-Ladewig, Principal Characteristics of the New ECHR Control Mechanism, as Established by Protocol No. 11, Signed on 11 May 1994, 15 HUM. RTS. L.J. 81 (1994).

67. European Convention, supra note 56, art. 53. The European Court submits its judgments to the Committee of Ministers, which supervises their execution. Id. art. 54 .

68. Id. art. 50.

69. International extradition is "a formal process by which a person is surrendered by one state to another." $1 \mathrm{M}$. CHERIF BASSIOUNI, INTERNATIONAL EXTRADITION: UNITED STATES LAW AND PRACTICE 8 (2d ed. 1987). Generally, extradition between States is governed by treaty. $1 d$. at 10 ("The duty to extradite only by virtue of a treaty . . . has becoine the prevalent practice among states."). Extradition treaties establish the procedures a State must follow when seeking extradition, and obligate a State holding a fugi- 
have held that States' human rights obligations extend not only to their citizens but also to individuals within their jurisdictions who are the subjects of extradition proceedings, regardless of whether the State seeking extradition is a party to the human rights treaty. ${ }^{70}$ The cases demonstrate a clear trend toward the emergence for many States of an obligation to refuse extradition of an individual who faces a significant risk of receiving the death penalty in the receiving State unless the receiving State provides assurances that the death penalty will not be imposed or carried out. ${ }^{71}$

\section{A. Soering v. Umited Kingdom}

The plenary European Court of Human Rights unanimously decided the seminal case of Soering v. United Kingdom ${ }^{72}$ in 1989. Soering involved a challenge by Jens Soering, a young German national, to his extradition by the United Kingdom to the United States in order to face capital murder charges in Virginia. ${ }^{73}$ Soering complained that if the United Kingdom extradited him, it would be subjecting him to "imhuman or degrading treatment or punishment" ${ }^{34}$ in violation of its obligations under Article 3 of the European Convention, which provides that "[n]o one shall be subjected to torture or to mhuman or degrading treatment or pumishment."75 Soering argued that if he was extradited, he likely would be sentenced to death, ${ }^{76}$ and would face prolonged deten-

tive to extradite upon satisfaction of those procedures, subject to certain exceptions. See, e.g., Model Treaty on Extradition, U.N. GAOR 45th Sess., Agenda Item 100, U.N. Doc. A/RES/45/116 (1990), reprinted in 30 I.L.M. 1407 (1991). This Note will refer to the State seeking extradition as the "receiving State" and the State from which extradition is sought as the "harboring State."

70. See infra uote 79 and accompanying text; text accompanying notes 135-36.

71. See infra text accompanying notes 155-59.

72. 161 Eur. Ct. H.R. (ser. A) (1989), reprinted in 28 I.L.M. 1063 (1989).

73. Soering, 28 I.L.M. at 1071.

74. Id. at 1089.

75. European Conveution, supra note 56, art. 3.

76. Article IV of the Extradition Treaty between the Uuited Kingdom and the United States provides that "[i]f the offense for which extradition is requested is punishable by death under the relevant law of the reqnesting Party, but the relevant law of the requested Party does not provide for the death penalty in a similar case, extradition may be refused unless the requesting Party gives assurances satisfactory to the requested Party that the death penalty will not be carried out" Extradition Treaty, June 8, 1972, U.S.U.K., art. IV, 28 U.S.T. 227, 230. In accordance with Article IV, the United Kingdom had requested an assurance from the United States that Soering would not be subject to the death penalty. Soering, 28 I.L.M. at 1073. The Virginia prosecutor had agreed that if Soering were convicted of capital murder, he would inform the sentencing judge that "it 
tion on death row in severe conditions that would constitute inhuman and degrading treatment and punishment. ${ }^{77}$

The European Court held that, under the circumstances of the case, the extradition of Soering to face the serious likelihood of a death sentence in the United States would constitute a violation of Article 3 of the European Convention. ${ }^{78}$ In a sweeping declaration of the scope of a Contracting State's obligations under the Convention, the European Court held that

the decision by a Contracting State to extradite a fugitive may give rise to an issue under Article 3, and hence engage the responsibility of the State under the Convention, where substantial grounds have been shown for believing that the person concerned, if extradited, faces a real risk of being subjected to torture or inhuman or degrading treatment or punishment in the requesting country. ... In so far as any liability under the Convention is or may be incurred, it is liability incurred by the extraditing Contracting State by reason of its having taken action which has as a direct consequence the exposure of an individual to proscribed ill-treatment. ${ }^{79}$

The European Court based this principle on the Contracting State's obligation to ensure that all those within its jurisdiction receive the practical and effective protections provided by the Convention. ${ }^{80}$

is the wish of the United Kingdom that the death penalty should not be imposed or carried out." Soering argued, however, that this assurance was "worthless." Id. at 1073-74. The European Court agreed that the "assurance" did not eliminate the likelihood of Soering's being sentenced to death. Id. at 1095.

77. Soering, 28 I.L.M. at 1088.

78. Id. at $1100-01$.

79. Id. at 1093. This principle was not, in fact, new to the Soering case. Earlier decisions of the European Commission had indicated that, in certain extraordinary circumstances, extradition of an individual to face conditions proscribed by the Convention might invoke the responsibility of the extraditing state under the Convention. See Kirkwood v. U.K., App. No. 10479/83, 37 Eur. Comm'n H.R. Dec. \& Rep. 158, 182-83 (1984); Altun v. F.R.G., App. No. 10308/83, 36 Eur. Comm'n H.R. Dec. \& Rep. 209, 231-32 (1984). However, Soering was the first case in which the European Court embraced this principle.

80. See European Conveution, supra note 56, art. 1, at 224 ("The High Contracting Parties shall secure to everyone within their jurisdiction the rights and freedoms defined in Section I of this Convention."); see also Artico v. Italy, 37 Eur. Ct. H.R. (ser. A) (1980), reprinted in 3 Eur. H.R. Rep. 1, 13 (1981) (holding that defendant's right to counsel must be effective, not inerely theoretical or illusory). 
Applying the stated principle to extradition to face the death penalty, the European Court held that, although subjecting an individual to the death penalty per se did not constitute a violation of the provisions of Article $3,{ }^{81}$ the circumstances of detention on death row-the "death row phenomenon"-could reach the level of "inhuman" pumishment prohibited by Article $3 .^{82}$ The European Court cited four circumstances that supported its ruling that the extradition of Soering without a concrete assurance that the death penalty would not be imposed would violate Article 3: (1) the length of detention on death row prior to execution-an average six to eight years in Virgima; ${ }^{83}$ (2) the conditions on death row, including a severe custodial regime and the risk of hoinosexual abuse and physical attack,;4 (3) Soering's youthful age and possibly disturbed mental state at the time of the murders, ${ }^{85}$ and (4) the possibility that Soering could be extradited to face charges in the Federal Republic of Germany, which elininated the possibility that he might elude justice if not extradited. $^{86}$

81. Soering, 28 I.L.M. at 1097.

82. Id. at $1098,1100-01$.

83. Id at 1098. The European Court held that the length of detention can contribute to inhuman conditions even if the delay is due primarily to the appellate process and habeas corpus proceedings initiated by the prisoner. Id. This view is consistent with recent decisions by the Privy Council of the United Kingdom, Pratt v. Attorney General for Janaica, [1994] 2 App. Cas. 1, 33 (P.C. 1993) (appeal taken from Jam.) ("If the appellate procedure enables the prisoner to prolong the appellate hearings over a period of years, the fault is to be attributed to the appellate system that permits such delay and not to the prisoner who takes advantage of it."); the Supreme Court of India, Vatheeswaran v. State of Tamil Nadu, [1983] 2 S.C.R. 348, 353 (India) ("The cause of the delay is immaterial when the sentence is death. Be the cause for the delay, the time necessary for appeal and consideration of reprieve or some other cause for which the accused himself may be responsible, it would not alter the dehumanizing character of the delay."); and the Supreme Court of Zimbabwe, Catholic Commission for Justice and Peace in Zimbabwe v. Attorney-General, Supreme Court of Zimbabwe, unreported, available in 14 HUM. RTs. L.J. 323, 334 (1993) ("It seems to me highly artificial and unrealistic to discount the mental agony and torment experienced on death row on the basis that by not making the maximum use of the judicial process available the condemned prisoner would have shortened and not lengthened his suffering.") (quoted in Pratt, [1994] 2 App. Cas. at 31 ).

84. Soering, 28 I.L.M. at 1099.

85. Id. at $1099-1100$.

86. Id. at 1100 . The Federal Republic of Germany also had requested Soering's extradition because German criminal law provides for jurisdiction over German nationals accused of crimes committed outside Germany. Id. at 1087. Because Germany abolished the death penalty in 1949, Soering could have been proseeuted for the murder in Germany without the risk of receiving the death penalty. Id. 
The Soering decision is significant because it explicitly held that the obligations of Contracting Parties to the European Convention apply to all persons within their jurisdictions, including those who are the subjects of extradition proceedings, regardless of whether the receiving State is also a Contracting Party to the Convention. ${ }^{87}$ Thus, a Contracting Party may be obligated under the European Convention to refuse extradition to the United States or seek assurances that the death penalty will not be carried out when extradition nay ultimately lead to the imposition of the death penalty.

The European Court also stated that the content of the Article 3 prohibition against cruel and unusual punishment is determined by the evolving standards of the Contracting Parties. ${ }^{88}$ According to this principle, as the Contracting Parties to the Convention move toward a uniform condemnation of the death penalty, ${ }^{89}$ the European Court may find that the death penalty per se is inhuman or degrading treatment or punishment in violation of Article 3 of the Convention. Upon such a finding, all Contracting Parties would be forbidden to extradite anyone withm their jurisdictions to face the death penalty.

\section{B. Short v. The Netherlands}

In Short v. The Netherlands, the High Court of the Netherlands addressed a situation in which a Contracting Party to both the European Convention and its Sixth Protocol, which requires a Contracting Party to abohish the death penalty absolutely, ${ }^{90}$ received a request to extradite an individual to face the death penalty. ${ }^{91}$ Short involved a request by U.S. military authorities for the

87. Id. at $1091-92$.

88. Id. at $1096-97$.

89. As of December 31, 1993, 20 of the then 28 States party to the European Convention had ratified the Sixth Protocol to the Convention, AMNESTY INTERNATIONAL REPORT 351 (1994), which states: "The death penalty shall be abolished. No one shall be condemned to such penalty or executed." Protocol No. 6 to the Convention for the Protection of Human Rights and Fundamental Freedoms Concerning the Abohition of the Death Penalty, art. I, April 28, 1983, Europ. T.S. No. 114 (entered into force March 1, 1985), reprinted in 22 I.L.M. 538 (1983) [heremafter Sixth Protocol]. Only 14 States had ratified the Protocol at the time of the Soering decision. AMNESTY INTERNATIONAL REPORT 290 (1990).

90. Sixth Protocol, supra note 89 , art. 1.

91. Nos. 13.949, 13.950, excerpted and translated in 29 I.L.M. 1388 (1990). The decision excerpted is a summary decision. The court's reasoning discussed herein is that con- 
extradition of U.S. Staff Sergeant Charles Short in order to prosecute him for a murder he committed while stationed in the Netherlands. ${ }^{92}$ After Dutch police arrested Short and he confessed to the murder of his wife, the United States requested that Short be extradited to U.S. nilitary personnel pursuant to the NATO Status of Forces Agreement (NATO SOFA) ${ }^{93}$ to face court-martial for capital murder. ${ }^{94}$ Although the United States refused to guarantee that the death penalty would not be imposed on Short, the Dutch State Secretary agreed to extradite Short. ${ }^{95}$ Short appealed to the High Court, arguing that if the Netherlands extradited him to face court-martial for capital murder, it would commit a tort against him by violatimg the rights it was obligated to afford him under the European Convention and the Sixth Protocol. ${ }^{96}$

The High Court first ruled that the Netherlands was obligated to secure to Short all the rights and freedoms guaranteed by the European Convention because he was an imdividual withm its jurisdiction. ${ }^{97}$ The High Court then considered precisely what

tained in the Opinion of Advocaat-Generaal Strikwerda, excerpted and translated in 29 I.L.M. 1378 (1990), which was adopted by the court in its brief statement of the grounds for its decision. Short, 29 I.L.M. at 1389.

92. Leonard H. W. van Sandick, The Netherlands: Opinion of the Advocaat-Generaal and Supreme Court Decision in The Netherlands v. Short: Introductory Note, 29 I.L.M. 1375, 1375 (1990).

93. Agreement Between the Parties to the North Atlantic Treaty Regarding the Status of Their Forces, June 19, 1951, 4 U.S.T. 1792, 199 U.N.T.S. 67. The relevant provisions are

Art. VII, paragraph 3(a)(i): The military authorities of the sending State shall have the primary right to exercise jurisdiction over a member of a force ... in relation to ... offenses solely agamst the person or property of ... a dependent [of a member of the force];

Art. VII, paragraph 5(a): The authorities of the receiving and sending States shall assist each other in the arrest of members of a force or civilian component or their dependents in the territory of the receiving State and in handing them over to the authority which is to exercise jurisdiction in accordance with the ... provisions [of the Article].

Id. at 1800, 199 U.N.T.S. at 78. Although the NATO SOFA agreement refers to the process of transferring custody of prisoners as "handing over," the Short court held that the distinction between "handing over" and "extradition" was irrelevant to the Netherlauds obligations under the European Convention. Short, 29 I.L.M. at 1384 ("The essential point is whether the conduct of the State will have as a result that the person concerned will be exposed to the forbidden treatment, irrespective of the juridical qualification of the act of transmission."). Therefore, to avoid confusion, this Note will refer to Short's "handing over" proceedings as extradition proceedings.

94. See 10 U.S.C. $\S 918$ (1994).

95. Short, 29 I.L.M. at 1378.

96. Id.

97. Id. at 1382; see also European Convention, supra note 56, art. 1 ("The High 
those rights and freedoms were. The High Court held that the European Convention and Sixth Protocol, when read together, obligated the Netherlands not to subject Short to the death penalty. ${ }^{98}$ The Netherlands, by ratifying the Sixth Protocol, had indicated that it "consider[ed] imposition and execution of the death penalty inhuman treatment which art. 3 of the European Convention forbids." ${ }^{.99}$ In light of the Soering judgment, the Netherlands could not extradite an individual to face such inhuman treatment:

[A] state which is a party to the Sixth Protocol and proceeds with extradition for an act which is subject to the death penalty under the legislation of the requesting State, acts in conflict with art. 2 as well as art. 3 of the European Convention, if it can be assumed on valid grounds that the requested person after extradition runs a real chance of being condeinned to death and the possibility that the death penalty will be executed on him is not excluded. ${ }^{100}$

Thus, the High Court held that the Netherlands would commit a tort against Short if it extradited him to the U.S. military authorities, and ordered that he not be extradited without a guarantee from the Umited States that the death penalty would not be imposed on him. ${ }^{101}$

Contracting Parties shall secure to everyone within their jurisdiction the rights and freedoms defined in Section I of this Convention.").

98. Short, 29 I.L.M. at 1383.

99. Id.

100. Id. at 1384. Article 2 of the European Convention provides that "[n]o one shall be deprived of his life intentionally save in the execution of a sentence of a court following his conviction of a crime for which this penalty is provided by law." European Convention, supra note 56, art. 2.

101. Id. The High Court also expressed regret that its decision might allow Short to evade justice, and stated its hope that its decision would induce the United States to grant the requested guarantee that the death penalty would not be imposed. Id. at 1387-88. After the High Court's decision, the United States and Dutch authorities agreed that Short, while technically renuaining in Dutch custody, would submit to a pretrial investigation and psychiatric evaluation by U.S. military authorities, and would be extradited only if the U.S. court-martial decided not to prefer Short for a capital crime. Major John E. Parkerson, Jr. \& Major Carolyn S. Stoehr, The U.S. Military Death Penalty in Europe: Threats From Recent European Human Rights Decisions, 129 ML. L. REV. 41, 72 n.174 (1990) (citing Telecommunications Message from AMEMBASSY THE HAGUE to SECSTATE Washington (U) (June 6, 1990), subject: SGT Short Murder Case: Psychiatric Evaluation: Status Report). The court-martial convening authority ultimately referred Short's case as noncapital, and he was released to United States custody by Dutch anthorities. See United States v. Short, ACM 29628, 1993 C.M.R. LEXIS 315, at *6 (A.F.C.M.R. 1993). 
The Short decision, although binding only in the Netherlands, suggests the likely obligations of all Contracting Parties to both the European Convention and the Sixth Protocol. The Dutch High Court's analysis of the effect of ratification of the Sixth Protocol on a Contracting Party's obligations under Article 3 of the European Convention is logical and consistent with the European Court's Soering decision. The European Court declared in Soering that a Contracting Party's obligations under Article 3 are dependent on evolving standards of what constitutes inhuman or degrading treatment or punishment. ${ }^{102}$ By ratifying the Sixth Protocol, a Contracting Party declares that its standards have evolved to the point where it considers the deatl penalty to be inhunan treatinent and is willing to undertake a legal obligation to that effect. ${ }^{103}$ A Contracting Party to the Sixth Protocol therefore is obligated not to subject anyone within its jurisdiction to the deatl penalty. Under the Soering principle, that obligation applies to individuals who are the subjects of extradition proceedings. Thus, Contracting Parties to the European Convention and Sixth Protocol are obligated not to extradite anyone who faces a significant risk of execution.

Admittedly, this obligation to refuse extradition raises the possibility that Contracting Parties to the European Convention and Sixth Protocol may become "safe lavens" for capital crimi-" nals. ${ }^{104}$ However, the Soering and Short cases, which both resulted in the transfer of the fugitives to U.S. custody and assurances by the United States that the deatlı penalty would not be inposed, ${ }^{105}$ suggest the inore likely outcome of refusals to extradite: The United States will, when necessary, provide assurances that the death penalty will not be imposed; the fugitives will be extradited; and prosecutors will exercise their discretion to bring noncapital charges against the extradited individuals. Thus, "safe haven" concerns probably will not proinpt the European Court or Contracting Parties to the European Convention and Sixth Proto-

102. Soering v. United Kingdonl, 161 Eur. Ct. H.R. (ser. A) (1989), reprinted in 28 I.L.M. 1063, 1097 (1989).

103. See supra text accompanying note 99.

104. See Soering, 28 I.L.M. at 1092; see also Short, 29 I.L.M. at 1387.

105. See Richard B. Lillich, Conment, The Soering Case, 85 AM. J. INT'L L. 128, 141 (1991) (describing U.S. assurances that no capital charges would be brought against Soering); supra note 101. 
col to retreat from their understanding of their obligations with respect to extradition of individuals to face the death penalty.

\section{Kindler v. Canada and Ng v. Canada}

Despite the strong European commitunent to human rights obligations with respect to extradition to face the death penalty, recent decisions of the Supreme Court of Canada and the United Nations Human Rights Committee have limited the scope of the Soering principle. However, the UNHRC decisions both reinforce the principle that international human rights obligations apply to extradition decisions and increase the likelihood that future Canadian extradition decisions will be influenced by international obligations.

Joseph Kindler was convicted of murder and kidnapping in Pennsylvania, and the jury recommended that he be sentenced to death. Prior to his sentencing, Kindler escaped from custody and fled to Canada, where he was arrested. The United States requested his extradition, and extradition was ordered by the Superior Court of Quebec. ${ }^{106}$ Charles Chitat $\mathrm{Ng}$ also fled to Canada to avoid prosecution for inurder. He was arrested by Canadian authorities, and the United States requested that he be extradited to California to face criminal charges for which he could receive the death penalty. ${ }^{107} \mathrm{~A}$ Canadian court ordered his extradition in November 1988.

Pursuant to Article 6 of the Extradition Treaty between the United States and Canada, ${ }^{108}$ both Kindler and $\mathrm{Ng}$ petitioned the Canadian Minister of Justice to request assurances from the Unit-

106. Kindler v. Canada, Comm. No. 470/1991, Views of the UN Human Rights Committee, adopted on 30 July 1993, I 2.1, available in 14 HUM. RTS. L.J. 307 (1993) [hereinafter Kindler Views].

107. In re $\mathrm{Ng}$ Extradition, [1991] 2 S.C.R. 858, 863 (Cory, J., dissenting).

108. Treaty on Extradition, Dec. 3, 1971, Can.-U.S., Art. 6, 27 U.S.T. 983, 983.

When the offense for which extradition is requested is punishable by death under the laws of the requesting State and the laws of the requested State do not permit such punishment for that offense, extradition may be refused unless the requesting State provides such assurances as the requested State considers sufficient that the death penalty shall not be imposed, or, if imposed, shall not be executed.

The Article is applicable because Canada abolished the death penalty for all but a few military offenses in 1976. See Criminal Law Alnendment (No.2), July 16, 1976, cl. 105., § 5, 1974-75-76 S.C. $2127,2129-30$ (Can.) (revising Canadian Criminal Code to eliminate possibility of death sentence for murder). 
ed States that the death penalty would not be imposed on them. The Minister of Justice demied both requests, primarily because he feared that a routme practice of seeking assurances agamst the imposition of the death penalty would encourage capital fugitives from the United States to seek haven in Canada in order to reduce the severity of their punishments. ${ }^{109}$ Kindler and $\mathrm{Ng}$ both petitioned the Supreme Court of Canada and the United Nations Human Rights Committee to review the decisions of the Minister of Justice.

In the cases before the Canadian Suprenie Court, Kindler and $\mathrm{Ng}$ both argued that the failure of the Minister of Justice to condition their extraditions to the United States on the receipt of assurances that the death penalty would not be imposed violated sections 7 and 12 of the Canadian Charter of Rights and Freedoms. ${ }^{110}$ These sections provide, respectively, that no person shall be deprived of "life, hiberty and security of the person . . . except in accordance with the principles of fundamental justice," and that "[e]veryone has the right not to be subjected to any cruel and unusual treatment or punishment." Kindler and $\mathrm{Ng}$ argued that (1) the death penalty per se, (2) the particular method of execution, and (3) the "death row phenomenon" created by prolonged detention on death row, constituted cruel and unusual treatment or punishment to which they could not be subjected, through extradition, imder section 12. They further argued that because the imposition of the death penalty did not accord with Canadian principles of fundamental justice, extradition to face the penalty deprived then of life and hiberty in violation of section 7 of the Charter. ${ }^{111}$

The Canadian Supreme Court decided the Kindler and $\mathrm{Ng}$ cases together. The Canadian Court ruled, in a strongly contested 4-3 decision, that extradition without assurances did not violate the provisions of the Canadian Charter. ${ }^{112}$ Justice La Forest, writimg for the majority, first held that the Minister's decision to

109. Kindler v. Canada (Minister of Justice), [1991] 2 S.C.R. 779, 796 (Cory, J., dissenting); $\mathrm{Ng}$, [1991] 2 S.C.R. at 863-64 (Cory, J., dissenting).

110. Kindler, [1991] 2 S.C.R. at 780; $\mathrm{Ng}$, [1991] 2 S.C.R. at 859. The Canadian Charter of Rights and Freedoms, a part of the Constitution Act of 1982, is reproduced in 1 C.R.R. 1 (1982).

111. Kindler, [1991] 2 S.C.R. at 780-81.

112. Id. at 780; $\mathrm{Ng}$, [1991] 2 S.C.R. at $859-60$. The arguments supporting the Canadian Court's decisions are set forth in the Kindler opinion. 
extradite did not constitute cruel and unusual treatment or punishment in violation of section 12 of the Charter. ${ }^{113}$ Because the death penalty would, if imposed, be carried out by U.S. officials within the United States against a U.S. citizen for a crime coinmitted in the United States, the Minister of Justice could not be held responsible for that action. ${ }^{114}$

Turning to section 7, Justice La Forest held that the Kindler and $\mathrm{Ng}$ extraditions would not violate Canadian principles of fundainental justice unless extradition would subject the petitioners to conditions "so unacceptable as to 'shock the conscience" of the Canadian community. ${ }^{115}$ Justice La Forest found that extradition to face the death penalty would not "shock the conscience" of the Canadian citizenry based on the following three factors: reinstateinent of the death penalty had been voted down in 1987 by a relatively narrow margin; public opimion statistics indicated that extradition to face the death penalty would not be an outrage to the public conscience, ${ }^{116}$ and, despite the trend among Western nations, there was no custoinary norm of international law against the death penalty. ${ }^{117}$

Justice La Forest also echoed the Minister of Justice's desire that the extradition of capital criminals to the United States reinain unhindered by the Charter because of the threat that Canada might becoine a safe haven for criminals who face the possibility of a death sentence $\mathrm{m}$ the United States. ${ }^{118}$ Finally, Justice La Forest dismissed the arguments regarding the "death row phenoinenon" and the method of execution, finding that those factors did not raise the conditions of extradition over the "shock the conscience" threshold. ${ }^{119}$

113. Kindler, [1991] 2 S.C.R. at 831.

114. Id. This view of the responsibility of a harboring State for the subsequent treatment of an extradited individual is directly opposed to the Soering principle.

115. Id. at 832 (quoting Schmidt v. Canada, [1987] 1 S.C.R. 500, 522).

116. Id.

117. Id. at 834.

118. Id. ("The Government has the right and duty to keep ont and to expel aliens from this country if it considers it advisable to do so .... It would be strange if Canada could expel lesser criminals bnt be obliged by the Charter to grant sanctuary to individuals who were wanted for crimes so serious as to call for the death penalty in their country of origin.")

119. Id. at 838 (noting that delays on death row are due primarily to the voluntary prosecution of appeals by the prisoners themselves, and that there may not be more humane methods of execution than electrocution). 
The decision of the majority, however, was far from decisive. Three justices dissented on two grounds. Justice Sopinka argued that under section 7 of the Charter, extradition to face the death penalty was contradictory to Canadian principles of fundamental justice. He argued that principles of fundamental justice are violated whenever an individual is extradited to "face a situation that is simply unacceptable." ${ }^{120}$ Under this standard, Justice Sopinka concluded that "it offends the principles of fundamental justice not to seek assurances agamst the imposition of what would be a violation of s. 12, were it carried out in Canada."121 Finally, he dismissed the "safe haven" argument on the ground that it was not clear that fugitives would elude justice if assurances were sought because the United States probably would provide assurances if extradition were conditioned on their issuance. ${ }^{122}$

Justice Cory dissented on the gromd that section 12 of the Charter prohibited extradition to face the death penalty. He argued that the death penalty clearly constituted cruel and unusual pumishment under section $12 .{ }^{123}$ Justice Cory then asserted that the protections of section 12 applied even though the death penalty would be carried out im the United States. Justice Cory cited Canadian authority ${ }^{124}$ and the Soering judgment ${ }^{125}$ to support

120. Id. at 791 (Sopinka, J., dissenting) (quoting United States v. Allard, [1987] 1 S.C.R. 564, 572) (emphasis added).

121. Id. at 792. Justice Sopinka assumed that the abolition of the death penalty in Canada reflected a behef that the penalty is a cruel and unusual punishment prohibited by section 12 of the Charter. Id.

122. Id.; see also supra note 105 and accompanying text (providing empirical support for Justice Sopinka's assumption).

123. Kindler, [1991] 2 S.C.R. at 813-15 (Cory, J., dissenting). Justice Cory cited the Charter's emphasis on human dignity and the Court's interpretation of the "cruel and unusual punishment" clause to support his conclusion. He summarized the principles governing the interpretation of section 12:

First, punishments must never be grossly disproportionate to that which would have been appropriate to punish, rehabilitate or deter the particular offender or to protect the public from that offender. Second, ... punishments must not in themselves be unacceptable no matter what the crime, no inatter what the offender .... [W] [hen a punishment becomes so demeaning that all human dignity is lost, then the punishment inust be considered cruel and unusual.

Id. at 815 (citing R. v. Smith, [1987] 1 S.C.R. 1045).

124. Id. at 819-20 (citing Schmidt v. Canada, [1987] 1 S.C.R. 500, 522); Argentina v. Mellino, [1987] 1 S.C.R. 536, 558; United States v. Allard, [1987] 1 S.C.R. 564, 572; Simgh v. Minister of Employment and Immigration, [1985] 1 S.C.R. 177, 207 ("' 'S] ecurity of the person' [as used in section 7 of the Canadian Charter] must encompass freedom from the threat of physical punishment or suffering as well as freedoun froin such punishment itself.")).

125. Soering v. United Kingdom, 161 Eur. Ct. H.R. (ser. A) (1989), reprinted in 28 
his conclusion that "Canada has the obligation not to extradite a person to face a cruel and unusual treatment or punishment. To surrender a fugitive who may be subject to the death penalty violates s. 12 of the Charter just as surely as would the execution of the fugitive in Canada." 126 Finally, Justice Cory dismissed the "safe haven" argument on the ground that there was no evidentiary support for this "in terrorem argument."127

Canada's human rights obhigations with respect to the Kindler and $\mathrm{Ng}$ extraditions also were considered by the United Nations Human Rights Committee (UNHRC). Canada is a party to the International Covenant on Civil and Political Rights (ICCPR) ${ }^{128}$ and the Optional Protocol providing for the riglit of individual petition to the UNHRC. ${ }^{129}$ Pursuant to these treaties, Kindler and $\mathrm{Ng}$ filed communications with the UNHRC seeking review of the decisions of the Canadian Suprenie Court. Kindler and $\mathrm{Ng}$ each alleged that the decision to extradite him violated Article 6 (right to life), Article 7 (prohibition against torture and cruel, inhuman, or degrading treatment or punishment), Article 9 (riglit to liberty and security of person), Article 10 (right of detained persons to be treated with humanity and respect for the inherent dignity of the human person), Article 14 (right to a fair trial), and Article 26 (prohibition agamst discrimination under the law) of the ICCPR. ${ }^{130}$ Both argued that the conditions on death row constituted cruel, inhuman, and degrading treatment or punishment, and that racial bias in the imposition of the death penalty rendered the trial leading to its imposition unfair. ${ }^{131}$ Kindler further argued that the death penalty per se constituted cruel, inhuman, and degrading punishment, ${ }^{132}$ and $\mathrm{Ng}$ argued that execution by gas aspliyxiation constituted cruel, inhuman, and degrading punishment. ${ }^{133}$

\footnotetext{
I.L.M. 1063 (1989).

126. Kindler, [1991] 2 S.C.R. at 824 (Cory, J., dissenting).

127. Id. at $825-26$.

128. ICCPR, supra note 55 .

129. Optional Protocol, supra note 58, arts. 1, 2.

130. Kindler Views, supra note 106, II 1; Ng v. Canada, Comm. No. 469/1991, Views of the UN Human Rights Committee, adopted on 5 November 1993, II 3 [hereinafter $\mathrm{Ng}$ Views].

131. Kindler Views, supra note 106, II 3; Ng Views, supra note 130, II 3.

132. Kindler Views, supra note 106 , If 3.

133. Ng Views, supra note 130 , II 3.
} 
In both views, the Committee only considered Canada's obligations under Articles 6 and 7 of the ICCPR. ${ }^{134}$ In the Kindler views, the Committee adopted and reiterated the Soering principle:

[I]f a State party takes a decision relating to a person within its jurisdiction, and the necessary and foreseeable consequence is that that person's rights under the Covenant will be violated in another jurisdiction, the State party itself may be in violation of the Covenant .... The foreseeability of the consequence would mean that there was a present violation by the State party, even though the consequence would not occur until later on. ${ }^{135}$

The Committee further held in the $\mathrm{Ng}$ views that a "real risk" of violation can exist, even if the individual has not yet been convicted of a capital crime, if the imposition of the death penalty appears likely. ${ }^{136}$

In the Kindler views, the UNHRC found that Canada had not violated its obligations under the $\mathrm{ICCPR}^{137}$ for four reasons. First, the Committee found that extradition to face the death penalty for preineditated inurder did not violate the Article 6(1) right to life because Article 6(2) expressly permits the imposition of the death penalty for "the most serious crimes."138 Second, the Committee found that, in hight of the Article 6(2) exception, the death penalty itself did not constitute cruel, inhuman, or degrading treatinent or punishment in violation of Article 7.139 Third, although Canada had abolished the death penalty and should consider the attitudes of its citizens when determining whether or not to seek assurances that the death penalty will not be imposed, it was not obligated to seek such assurances in all cases. ${ }^{140}$ In Kindler's case, legitimate reasons justifying the decision not to seek assurances included the absence of exceptional circumstances mitigating against the imposition of the death penalty, the availability in the United States of due process to challenge the death sentence, and

134. Kindler Views, supra note 106, II 7. Apparently, the Committee felt that neither petitioner had presented sufficient evidence to support his other claims.

135. Id., 16.2 .

136. $\mathrm{Ng}$ Views, supra note 130, I 13.5.

137. Kindler Views, supra note 106, II 18.

138. Id., II 14.3.

139. Id., I 15.1 (stating that the ICCPR must be read as a whole, so that the Article $6(2)$ exception is relevant to the definition of cruel, inhuman, or degrading treatment or punishment).

140. Id., I 14.5 . 
the importance of preventing Canada from becoming a safe haven for capital criminals from the United States. ${ }^{141}$ Finally, the Committee found that the "death row phenomenon" did not violate Article 7 of the Covenant. ${ }^{142}$ The Committee reaffirmed an earher statement that "prolonged periods of detention under a severe custodial regime on death row cannot generally be considered to constitute cruel, inhuman or degrading treatment if the convicted person is inerely availing himself of appellate remedies." ${ }^{143} \mathrm{Al}-$ though the Committee recognized the validity of the Soering decision, it limited the decision closely to its facts. The Committee distinguished Kindler's case on the grounds of his age and mental state, the conditions of confinement on death row in Pennsylvama-about which Kindler had made no specific submissions-and the lack of an alternative jurisdiction in which Kindler could be brought to justice. ${ }^{144}$ Thus, the Cominittee concluded that Canada had not violated its obligations to Kindler under the ICCPR. ${ }^{145}$

In the $\mathrm{Ng}$ views, on the other hand, the Committee found that execution by gas asphyxiation violated the Article 7 prohibition against cruel, mhuman, and degrading punishment. ${ }^{146}$ The Committee cited its General Comment on Article 7 in holding that the death penalty must be carried out both im accordance with the provisions of Article 6(2) and "in such a way as to cause the least possible physical and mental suffering." 147 Because of the agony that an individual endures during the gas asphyxiation procedure, which can last over ten minutes, the Committee found that execution by gas asphyxiation failed to meet the "least possible suffer-

141. Id., \14.6.

142. Article 7 states: "No one shall be subjected to torture or to cruel, inhuman or degrading treatment or punishment." ICCPR, supra note 55, art. 7; Kindler Views, supra note 106, II 15.2.

143. Kindler Views, supra note 106, II 15.2 (quoting Martin v. Jamaica, Comm. No. 317/1988, Views of the UN Human Rights Committee, adopted on 24 March 1993, I 12.2).

144. Kindler Views, supra note 106, II 15.3 .

145. Id., II 18.

146. $\mathrm{Ng}$ Views, supra note 130 , II 16.4 .

147. Id., I 16.2 (quoting General Comment 20[44] on Article 7, UN Doc. CCPR/C/21/Add.3, para. 6). 
ing" standard and thus violated Article 7.148 Consequently, Canada's extradition of $\mathrm{Ng}$ violated the ICCPR. ${ }^{149}$

The $\mathrm{Ng}$ views, however, were not unanimous. ${ }^{150}$ Four members of the Committee dissented to the Article 6 findings. They argued that Article 6(2) did not apply to countries that had abolished the death penalty, so that these States are obligated under Article 6 to refuse extradition of capital criminals unless assurances are provided. In addition, four members of the Committee disagreed with the Article 7 finding on the ground that there was insufficient evidence that execution by gas asphyxiation was more cruel and inhuman than other methods of execution.

Both the Canadian Supreme Court and UNHRC Kindler decisions demonstrate that international human rights obligations will not, in all circumstances, prevent States from extraditing individuals to face the death penalty. The "safe haven" possibility apparently is perceived as a real threat, ${ }^{151}$ and has a significant impact on the willingness of national courts and international human rights bodies to require States to refuse requests to extradite capital fugitives. In addition, the UNHRC's reiteration of the principle that death row delays attributable to the prosecution of prisoner appeals do not constitute cruel, inhuman, or degrading treatment reveals the extent to which international, as opposed to regional, consensus on the death penalty is lacking. ${ }^{152}$ Nonetheless, the $\mathrm{Ng}$ views indicate that some measure of agreement exists at the international level against the imposition of the death penalty through cruel and degrading means. $\mathrm{Ng}$ also shows that a State's interests in avoiding the "safe haven" threat will not always override the State's international human rights obligations.

Furthermore, the UNHRC $\mathrm{Ng}$ case also raises the issue of comphance with international human rights obligations. In that case, despite the UNHRC's request that Canada stay Ng's extradition pending the Committee's consideration of lis case, Canada extradited $\mathrm{Ng}$ on the same day that the Canadian Supreme Court

148. $\mathrm{Ng}$ Views, supra note 130 , II 16.4 .

149. Id., I 17.

150. See id., Appendix, for individual views.

151. But see supra notes 122 and 127 and accompanying text (questioning the validity of the "safe haven" argument).

152. The lack of consensus at the international level is also apparent in the $\mathrm{Ng}$ dissents. See supra note 150 and accompanying text. 
dismissed his appeal. ${ }^{153}$ Thus, $\mathrm{Ng}$ was unable to benefit from the protection to which he was entitled under the ICCPR. However, although compliance with UNHRC views remaims essentially voluntary, ${ }^{154}$ the existence of an authoritative interpretation of the ICCPR that obligates States not to extradite individuals to face death by gas asphyxiation may still have two important effects. First, the decision will make it more difficult for Canada and other States party to the ICCPR to extradite without assurances in future cases similar to $\mathrm{Ng}$ 's because they may thereby incur international political disfavor. Second, the $\mathrm{Ng}$ views on death by gas asphyxiation will enhance the pohitical clout of States seeking assurances against the imposition of the death penalty by that method because such States can refer to an authoritative international opinion to support their objections.

\section{Summary}

The above cases deinonstrate that a significant portion of the international community is noving, admittedly with sone reservations, toward the point where international human rights obligations will require inany States to refuse to extradite individuals to the United States to face capital prosecution. It is now clearly established that States' human rights obhigations apply to extradition decisions and obligate States to refuse to extradite individuals who face a significant risk of being subjected to cruel and inhuman punishment in the receiving State. ${ }^{155}$ If the harboring State lias acceded to a treaty that requires the abolition of the death penalty, ${ }^{156}$ the death penalty per se will constitute cruel and inhuman punishment to which the State inay not subject anyone through extradition. ${ }^{157}$ Even if a State is not obligated by treaty to abohisl the death penalty, certain incidents of the adninistration of the death penalty, such as prolonged detention in harsh conditions on death row ${ }^{158}$ or the method of execution, ${ }^{159}$ may be

153. $\mathrm{Ng}$ Views, supra note 130 , If 2.5 .

154. See supra notes $60-61$ and accompanying text.

155. See supra notes 79, 98-100, 135-36 and accompanying text; see also Craig $\mathrm{R}$. Roecks, Extradition, Human Rights, and the Death Penalty: When Nations Must Refuse to Extradite a Person Charged with a Capital Crime, 25 CAL. W. INT'L L.J. 189, 217 (1994).

156. See, e.g., Sixth Protocol, supra note 89.

157. See supra text accompanying note 98.

158. See supra notes $82-84$ and accompanying text.

159. See supra text accompanying notes 146-48. 
deemed sufficiently cruel and inhuman to obligate the State to refuse extradition of anyone facing a significant risk of receiving a death sentence.

Canadian officials, whose extradition policies are likely to have the most significant impact in the United States because of Canada's proximity to and long border with the United States, have exhibited some reluctance to condition extradition on assurances that the death penalty will not be carried out. However, several factors suggest that this reluctance may dissipate in the near future. First, there were strong dissents to the Canadian Supreine Court decisions permitting extradition to face the death penalty, ${ }^{160}$ and several commentators have criticized the Canadian Court's analysis of the application of the Canadian Charter to extradition proceedings. ${ }^{161}$ Second, the persuasiveness of a crucial argument supporting the Canadian Court's decisions, the "safe haven" argument, is debatable. The United States has deinonstrated that it will provide, when necessary to obtain extradition, assurances that the death penalty will not be inposed. ${ }^{162}$ Thus, captial fugitives are unlikely to elude justice if assurances are demanded. Moreover, fugitives probably flee the country in an atteinpt to escape punishment altogether, not merely to reduce the pimishment they will receive. Thus, a regular Canadian practice of requesting assurances in extradition cases involving capital fugitives should not lead to an increase of criminal flight to Canada over other jurisdictions. Third, the UNHRC specifically has addressed Canada's obligations in this context since the Canadian Suprenne Court decisions. Althougl the UNHRC held that Canada was not obligated in all cases to refuse to extradite individuals to face the death penalty, ${ }^{163}$ the Committee also held that Canada's liuman rights obligations do apply to extradition decisions and obligate Canada to investigate conditions in receiving States and to refuse to extradite if those conditions constitute cruel and inhuman. punishment. ${ }^{164}$ Furthermore, although Canadian officials refused to

160. See supra notes 120-27 and accompanying text.

161. See, e.g., John Pak, Canadian Extradition and the Death Penalty: Seeking a Constitutional Assurance of Life, 26 CORNELL INT'L L.J. 239 (1993); Sharon A. Williams, Extradition to a State That Imposes the Death Penalty, 1990 CAN. Y.B. INT'L L. 117.

162. See supra note 105 and accompanying text.

163. See supra text accompanying notes $140-41$.

164. See supra text accompanying note 135 . This principle directly contradicts the Canadian Supreme Court's interpretation of the State's responsibility for punishments that 
postpone the extraditions of Kindler and $\mathrm{Ng}$ until after the UNHRC reviewed their cases, Canada will have greater difficulty disregarding its international human rights obligations now that those obligations have been stated clearly by the UNHRC. For these reasons, there is a strong possibility that Canada's interpretation of its obligations in the extradition context will shift in the future, and Canada will begin to condition extradition on assurances that the death penalty will not be imposed.

Thus, the international decisions demonstrate that, despite U.S. Supreine Court statements to the contrary, ${ }^{165}$ the U.S. criminal justice system can no longer remain isolated from the imternational community. The administration of the death penalty will be subject to international scrutimy, and when extradition of capital criminals is sought, decisions regarding capital prosecutions may be affected by the judgments that such international scrutiny yields.

\section{ARbitrariness and the Death Penalty IN the INTERNATIONAL EXTRADITION CONTEXT}

The administration of the death penalty in the existing international context is unconstitutional because it fails to satisfy either component of the Supreme Court's procedural requirements for the penalty's constitutional inposition. A decision to forego capital prosecution to facilitate extradition of an accused individual from a harboring State that opposes the death penalty is not based upon any factor related to the accused's character or the characteristics of his crime. Furtliermore, when death penalty decisions are influenced by a factor unrelated to the defendant or his crime, the evenhanded and consistent imposition of the death penalty is compromised.

Admittedly, a particular defendant's constitutional right to be free froin cruel and unusual punishment is not violated when that defendant is involved im an extradition proceeding though which the liarboring State's international lruman riglits obligations affect

take place after extradition. See supra text accompanying note 114.

165. See Stanford v. Kentucky, 492 U.S. 361, 369 n.1 (1989) ("We emphasize that [in determining whether a particular application of the death penalty violates evolving standards of decency] it is American conceptions of decency that are dispositive, rejecting the contention of petitioners and their various amici... that the sentencing practices of other countries are relevant."). 
the prosecution of the defendant. Such a defendant escapes capital punishment, and the Supreme Court explicitly has held that

[n]othing in any of our cases suggests that the decision to afford an individual defendant mercy violates the Constitution. Furman held only that ... the decision to impose it had to be guided by standards so that the sentencing authority would focus on the particularized circumstances of the crime and the defendant. . $^{166}$

Nonetheless, the death penalty systent as a whole is administered in an arbitrary and unconstitutional manner when the imternational pohtical system withm which it operates clearly inıposes on participating States an obligation, in certam circumstances, to coercively influence death penalty decisions. In such a systen1, every affirmative decision to inipose the death penalty would be different except for the nonexistence-or the existence of the lack-of a single extrinsic factor unrelated to the defendant's character or crime. Thus, every such affirmative death penalty decision is tainted by the influence of that extrimsic, and constitutionally inipermissible, factor.

A liypotlietical illustration froin a different context niay help to clarify the assertion. Suppose that a group of defendants are tried for capital offenses under a death penalty statute similar to the Georgia statute uplield in Gregg v. Georgia. ${ }^{167}$ All the defendants tried for capital offenses are African-American. Not all the defendants tried receive the death penalty; those that do are sentenced by juries that (1) affirmatively found a statutory aggravating circumstance, (2) considered all aggravatimg and nitigating circuinstances, and (3) determined that those circumstances weighed in favor of sentencmg the defendants to death. Thus, all affirmative decisions to inipose the death penalty were guided by the statutes, and each death penalty sentence was based not on race, but on the proper consideration of relevant factors. However, suppose further that the reason that no white defendants were charged with capital crimes, and that all the defendants sentenced to death happened to be African-American, ${ }^{168}$ is that in eacls

166. Gregg v. Georgia, 428 U.S. 153,199 (1976) (emphasis added).

167. See supra notes 33-37 and accompanying text.

168. Obviously, this hypothetical unrealistically divides all defendants into only two races. This is done for the sole purpose of keeping the hypothetical simple and does not stem from a lack of awareness of the much more diverse racial makeup of American society. 
white defendant's case, the prosecutor made the constitutionally permissible decision to "afford [that] individual defendant mercy."169 Furthermore, suppose that the decision to afford mercy was based on the fact that the defendant was white. In such a case, one would not hesitate to recognize that the system as a whole, and thus each affirmative death penalty decision inade within the system, is tainted by consideration of the race of the defendant-a factor that is universally recognized as an impermissible consideration in death penalty decisions. ${ }^{170}$ Although each death sentence, examined individually, appears to have been imposed in accordance with the procedural safeguards required under the Supreme Court's Eighth Amendment jurisprudence, the examination of the entire process reveals that the race of the defendants sentenced to death in fact played an unconstitutional role in their individual sentencing decisions because their nonwhiteness diminished the chances that they would be afforded mercy.

Similarly, the fact that defendants who flee to anti-death penalty States can escape capital prosecution has an impermissible influence on affirmative death sentances imposed on defendants who do not flee. Of the entire pool of defendants that might be subjected to capital prosecution, every defendant who actually faces capital charges does so partly because of her failure to flee to a State opposed to the death penalty. In other words, some defendants are eliminated from the pool of those facing capital prosecution because they have fled to a State that requires such elimination as a condition for extradition; those that remain in the pool do so partly because they failed to flee to such a State. Thus, the capital defendant's failure to flee affirmatively contributes to the imposition of the death penalty. Because this "failure to flee" circumstance is not related to the defendant's character ${ }^{171}$ or crimie, and it is not permissibly a consideration in death penalty

169. See Gregg, 428 U.S. at 199.

170. See McCleskey v. Kemp, 481 U.S. 279, 309 n.30 (1987) (listing Supreme Court cases intended to eradicate racial prejudice from criminal proceedings, including capital sentencing procedures).

171. One might legitimately argue that whether or not one flees the country after committing a capital crime does reflect on one's character. However, flight most likely signifies a lack of remorse for the crime, which properly should be an aggravating circumstance. Because flight in fact operates as a "mitigating" circnmstance and prevents a defeudant from receiving the death penalty, the influence of the "failure to flee" factor on death penalty decisions cannot be excused as the permissible influence of a facet of the defendant's character. 
decisions. ${ }^{172}$ Its influence, therefore, renders the death penalty system unconstitutional.

The "failure to flee" factor, although extrinsic to the defendant's character and crime, admittedly is not as inflammatory or objectionable on its face as the racial factor described in the above hypothetical. However, when one considers that the factors that are likely to contribute to a defendant's decision to flee the country or not-access to funds, availability of a passport, and the awareness that flight could enable the defendant to avoid the death penalty - are closely limked to a defendant's class and level of education, the objectionable nature of the influence of that decision on the defendant's chances of being sentenced to death becomes more apparent.

Soine additional criticisms of the assertion that the death penalty is unconstitutional should be addressed. First, defendants within the United States soinetimes receive different punishments for similar crimes because of the rather arbitrary fact that the crimes were committed in different states. Because the Constitution assigns primary responsibility for criminal punishment to the states, ${ }^{173}$ states are free to assign punishments different from those assigned in other states for the same crimes. Yet the Supreme Court has never held that a punishment, including the death penalty, imposed in one state is arbitrary because it is more severe than that which could have been imposed in another state. However, the failure of the Suprenie Court to object to the uneven imposition of pumishments across state bines within the United States does not undermine the argument presented here.

The Constitution simply does not require evenhanded punishments across state lines; rather, it allows each state, within the constraints of the Eighth Amendnient, to determine appropriate criminal punishments. The Supreme Court has held, however, that the Constitution requires the evenhanded administration of the death penalty within any state that has chosen to impose the penalty. ${ }^{174}$ This Note argues that such evenhanded administration, within a particular state, is coinpromised by the influence of ex-

172. See supra note 52 and accompanying text.

173. See U.S. CONST. art. I (enumerating limited powers granted to Congress); U.S. CONST. amend. X (reserving powers not granted to Congress to the states).

174. See Jurek v. Texas, 428 U.S. 262, 276 (1976); supra notes 45-49 and accompanying text. 
trinsic factors in the international extradition context. The death penalty is not arbitrary because people in other countries are not subject to it; rather, it is arbitrary because international opposition to the death penalty impermissibly affects the administration of the penalty within each state that has chosen to impose it. ${ }^{175}$ This argunient has never arisen in the domestic context because the fact that some states refuse to impose the death penalty cannot affect the administration of the death penalty within the other states. The Constitution obligates states to extradite to other states "on Demand of the executive Authority of the State."176 Thus, a state cannot constitutionally refuse to extradite because it opposes the use of the death penalty, and differing state views on the penalty cannot affect the administration of the penalty within the states that impose it.

A second objection imight be that because discretionary decisionmaking arguably is inherent in the criminal justice system, occasional anomalous cases like those in which foreign States' hunian rights obligations affect death penalty decisions are not unacceptable. However, although the Supreme Court has indicated a willingness to tolerate some discretionary inconsistencies in death penalty decisions, ${ }^{177}$ it also has stated that "[t]he Constitution is not offended by inconsistency in results based on the objective circumstances of the crime." The implication of the Court's qualification is that inconsistencies based on some factor other than the objective circunistances of the crime will offend the Constitution. Thus, sentencing disparities based on whether or not the defendant fled to a State opposed to the death penalty render the administration of the death penalty inconsistent with the require-

175. It is appropriate to attribute the effects of international human rights obligations on the administration of the death penalty to all states that impose it because the U.S. government negotiates the extradition treaties that allow harboring States to require assurances that the death penalty will not be imposed, and states always must seek extradition through the U.S. Department of State.

176. See U.S. ConST. art. IV, § 2, cl. 2 ("A Person charged in any State with Treason, Felony, or other Crime, who shall flee from Justice, and be found in another State, shall on Deinand of the executive Authority of the State from which he fled, be delivered up, to be removed to the State having Jurisdiction of the Crime.").

177. See, e.g., McCleskey v. Kemp, 481 U.S. 279, 313 (1987) ("Where the discretion that is fundamental to our criminal process is involved, we decline to assume that what is unexplained is invidious."); see also id. at $312 \mathrm{n} .35$ ("No one contends that all sentencing disparities can be ehminated.").

178. Id. at 307 n.28 (einphasis added). 
ments of the Constitution. Moreover, the Court has stated that the severe and irreversible nature of the death penalty makes the influence of impermissible factors on death penalty decisions particularly reprehensible. ${ }^{179}$ Therefore, discretionary inconsistencies that may be tolerated in criminal sentencing in general are unacceptable in the context of the death penalty.

Finally, and perhaps most persuasively, one might argue that because the types of extradition incidents described here occur so infrequently, ${ }^{180}$ the impact on the death penalty system as a whole is so minimal that one cannot argue that the entire systein is rendered arbitrary. The response to this objection is twofold. First, such cases may become nore frequent as States' obligations to refuse extradition are clarified, ${ }^{181}$ awareness of the possibility of escaping capital purnshment through flight increases, ${ }^{182}$ and technological advances lead to increased international travel. It is useful to anticipate the effect that such an increase in the occurrence of these extradition cases will have on the adininistration of the death penalty in the United States. Second, regardless of the limited de facto influence that international human rights obligations presently have on death penalty decisions, the description of that influence remains significant. The illustration of how international human rights obligations affect all death penalty decisions reveals how decisions not to seek the death penalty are relevant to determining whether the death penalty on the whole is administered fairly. Consequently, the argument challenges the Supreme Court's view, expressed in McCleskey v. Kemp, that courts should presume that death penalty decisions are fair absent proof of the

179. See, e.g., Furman v. Georgia, 408 U.S. 238, 309-10 (1972) (Stewart, J., concurring); id. at 311-12 (White, J., concurring).

180. The four cases discussed herein appear to be the only-or at least the only wellpublicized-instances in which the possible imposition of the death penalty became an issue in extradition proceedings. Moreover, unlike the hypothetical race example in which all white defendants were excluded from capital prosecution, international human rights obligations do not operate to exclude all or only wealthy, well-educated defendants from capital prosecution.

181. See Parkerson \& Stoehr, supra note 101, at 72-76 (arguing that the conflict between European and U.S. attitudes toward the death penalty and the principles enunciated in the Soering and Short cases pose a significant threat to the exercise of U.S. jurisdiction over capital cases involving U.S. military personnel stationed in NATO countries).

182. See Roecks, supra note 155, at 232 (arguing that as capital criminals become aware of the possibility of avoiding the death penalty by fleeing to a State opposed to the death penalty, death penalty opponents will develop an "underground railroad" to smuggle fugitives). 
influence of invidious decisional factors at the sentencing stage of a particular defendant's capital trial. ${ }^{183}$ The analysis here suggests that courts must be willing to examine the system of capital punishment as a whole to determine whether impermissible factors bear upon who ultimately is sentenced to death. If such an examination reveals that impermissible factors influence the makeup of the pool of defendants that is subjected to otherwise constitutional capital sentencing procedures, courts must be willing to hold that, despite what "most of the public seems to desire, and the Constitution appears to permit," unfairly and is thus unconstitutional.

The demonstration of the influence of an extrinsic factor im the international extradition context is also significant for another reason: It provides a framework for understanding the inevitability of the influence of other extrinsic factors on death penalty decisionmaking. The example presented here shows that the criminal justice system operates within a larger context--the international political coinmurity-and that efforts to insulate decisions made within the criminal justice system from the influence of irrelevant factors engendered by the surrounding context are futile. Thus, prosecutors in the United States cannot prevent international human rights obligations from influencing death penalty decisions because they have no control over foreign officials, who are free-and perhaps even obhgated-to refuse extradition unless provided with assurances that the death penalty will not be imposed.

The international extradition example can be extended by analogy to demonstrate the unavoidable influence of extrinsic factors from other surrounding contexts that affect the criminal justice system. Because actors within the criminal justice system generally cannot control the behavior of actors outside the systein, the system cannot insulate itself from the effects of the behavior of those other actors any more than it can insulate itself from actions taken by foreign officials. Thus, the influence of external

183. McCleskey, 481 U.S. at 319 ("It is the ultimate duty of courts to determine on a case-by-case basis whether these laws are applied consistently with the Constitution. Despite McCleskey's wide-ranging arguments that basically challenge the validity of capital punishment in our multiracial society, the only question before us is whether in his case .. the law of Georgia was properly applied.") (emphasis added).

184. Callins v. Collins, 114 S. Ct. 1127, 1131 (1994) (Blackmun, J., dissenting from denial of certiorari). 
societal factors on death penalty decisions is equally as unavoidable as the influence of international human rights obligations, and the arbitrariness of the administration of the death penalty is inevitable.

In fact, courts and legislatures generally recognize that the criminal justice system is not imsulated from its surrounding societal context, and accept the influence that societal factors have on the administration of justice. However, in the context of the death penalty, a uniquely severe punishment, ${ }^{185}$ courts presuine that decisionmaking can be imsulated from external factors. The demonstrated influence of international hunian rights obligations and the analogy it provides for understanding the influence of extrinsic factors engendered in other contexts exposes the fallacy of that presumption. Hopefully, it will provide the impetus for a greater recogmition on the part of courts and legislatures ahike that the arbitrariness of the death penalty is inevitable and that, therefore, the death penalty cannot be administered in accordance with our Constitution.

\section{CONCLUSION}

This Note examines the emerging willingness of anembers of the imternational commumity to act on their opposition to the death penalty by refusing to extradite anyone who faces a substantial likelihood of being sentenced to death. This international response to the Umited States' persistent use of the death penalty unpermissibly influences the administration of the death penalty in the United States and renders death penalty decisions arbitrary and capricious, and thus unconstitutional.

Admittedly, this argument is not likely to lead to a judicial deterinination that the death penalty as presently administered is arbitrary and capricious at a systematic level. Because international human rights obligations only infrequently operate through extradition proceedings to alter prosecutorial decisions to seek the death penalty, the impact that international obhgations have on the death penalty system as a whole is not readily apparent. Nonetheless, the argument still may serve two important purposes. First, it demonstrates the extent to which decisions inade before capital trials take place can affect the fairness of individual, affirmative

185. See Furman v Georgia, 408 U.S. 238, 286-91 (1972) (Brennan, J., concurring). 
capital sentencing decisions. This should prompt both courts and legislatures to reexamine the administration of the death penalty as a whole and reconsider whether death penalty statutes that merely guide jury discretion in the context of individual sentencing decisions adequately protect against the arbitrary imposition of the death penalty. Second, when conducting this proposed re-analysis of the administration of the death penalty, courts and legislatures should recognize from the international extradition example that factors unrelated to the characteristics of capital defendants or their crimes inevitably influence death penalty decisions. Thus, because the Eighth Amendinent of the Constitution, informed by "evolving standards of decency," imposition of the death penalty that inexorably results when factors unrelated to defendants or their crimes influence the decisionmaking process, the nation "eventually [should] conclude that the effort to eliminate arbitrarimess while preserving fairness in the infliction of [death] is so plainly doomed to failure that it-and the death penalty-must be abandoned altogether." "187

186. Trop v. Dulles, 356 U.S. 86, 101 (1958).

187. Callins, $114 \mathrm{~S}$. Ct. at 1138 (Blackmun, J., dissenting from denial of certiorari) (quoting Godfrey v. Georgia, 446 U.S. 420, 442 (1980) (Marshall, J., concurring in the judgment)). 
